Folia Cardiologica 2017 tom 12 , nr 1 , strony $118-123$ DOI: 10.5603/FC.2017.0017 Copyright (C) 2017 Via Medica ISSN 2353-7752

\title{
Najnowsze doniesienia kardiologiczne z kolebki światowego jazzu - relacja z AHA Scientific Sessions 2016 w Nowym Orleanie
}

\author{
Latest clinical trials from the birthplace of Jazz - Late Breaking Clinical Trials \\ at AHA Scientific Sessions 2016 in New Orleans
}

\author{
Dawid Miśkowiec, Jarosław D. Kasprzak \\ Katedra i Klinika Kardiologii Uniwersytety Medycznego w Łodzi
}

\section{Wstęp}

Kolejna edycja kongresu American Heart Association Scientific Sessions 2016, który odbywał się od 11 do 16 listopada 2016 roku w Nowym Orleanie - światowej kolebce jazzu - obfitowała w wiele ważnych wyników najnowszych badań klinicznych zaprezentowanych w ramach sesji Late Breaking Clinical Trials. Poniżej przedstawiono efekt subiektywnej selekcji najciekawszych z nich.

\section{Prewencja}

Jednym z ważniejszych badań z zakresu prewencji przedstawionych na ubiegłorocznym kongresie AHA było badanie EUCLID (Effects of Ticagrelor Compared with Clopidogrel in Patients with Peripheral Artery Disease) dotyczące pacjentów z objawową chorobą tętnic obwodowych (PAD, peripheral artery disease). Koncepcja badania opierała się na wcześniejszych obserwacjach klinicznych pacjentów z ostrymi zespołami wieńcowymi, dających przewage leczeniu tikagrelorem nad terapią klopidogrelem w postaci redukcji częstości zgonów, przypadków udaru mózgu oraz ponownego zawału serca. Badanie zaprojektowano w celu porównaniu długotrwałej monoterapii klopidogrelem względem monoterapii tikagrelorem w ograniczaniu złożonego punktu końcowego pod postacią zgonu sercowo-naczyniowego, zawału serca lub udaru niedokrwiennego mózgu u pacjentów z objawową PAD. Badaniem objęto 13885 pacjentów z objawową PAD zdefiniowaną jako wskaźnik kostka-ramię ( $\mathrm{ABI}$, ankle-brachial index) nie większy niż 0,8 lub przebycie rewaskularyzacji naczyń obwodowych ponad 30 dni przed włączeniem do badania. Chorych przydzielano losowo do grupy otrzymującej tikagrelor w dawce 2 razy $90 \mathrm{mg} /$ dobę lub klopidogrel w dawce $75 \mathrm{mg} /$ dobę (1:1). Zaprezentowane wyniki nie potwierdziły wyższości tikagreloru nad klopidogrelem w zakresie redukcji częstości niekorzystnych zdarzeń sercowo-naczyniowych (11,1\% v. 10,9\%; $p=0,72$ ) ani w zakresie bezpieczeństwa - istotne krwawienia występowały z identyczną częstością w grupach otrzymującej tikagrelor i przyjmującej klopidogrel (1,6\% v. $1,6 \% ; p=0,49)$. Niemniej jednak w grupie pacjentów otrzymującej tikagrelor obserwowano istotne zmniejszenie częstości udarów niedokrwiennych (1,9\% v. 2,4\%; współczynnik ryzyka [HR, hazard ratio] 0,78 (0,62-0,98). Wydaje się, że brak korzystnego efektu tikagreloru w zakresie redukcji częstości niekorzystnych zdarzeń obserwowanych we wcześniej przeprowadzonych badaniach w populacjach pacjentów z chorobą niedokrwienną serca (PLATO, PEGASUS-TIMI-54) można częściowo tłumaczyć faktem, że z badania EUCLID wykluczono pacjentów z polimorfizmem genu CYP2C19, a tym samym wyeliminowano ryzyko braku odpowiedzi na leczenie klopidogrelem [1].

Kolejnym oczekiwanym badaniem było badanie PRECISION (Prospective Randomized Evaluation of Celecoxib Integrated Safety versus Ibuprofen Or Naproxen). Zaprojektowano je w celu rozstrzygnięcia bezpieczeństwa sercowo-naczyniowego niesteroidowych leków przeciwzapalnych (NLPZ) z grupy koksybów - selektywnych inhibitorów cyklooksygenazy 2 (COX-2, cyclooxygenase 2). Niesteroidowe leki przeciwzapalne są najczęściej przepisywaną grupą leków 
na świecie. Badanie PRECISION zaplanowano w następstwie licznych kontrowersji wokół bezpieczeństwa stosowania koksybów, których źródłem były niekorzystne wyniki wcześniejszych badań obserwacyjnych oraz małych badań randomizowanych wskazujące na wzrost ryzyka incydentów sercowo-naczyniowych u chorych przyjmujących rofekoksyb. Do badania włączono pacjentów z chorobą zwyrodnieniową stawów lub reumatoidalnym zapaleniem stawów oraz współistniejącą chorobą układu sercowo-naczyniowego albo podwyższonym ryzykiem jej wystąpienia, którzy wymagali leczenia NLPZ przez co najmniej 6 miesięcy. Ostatecznie do badania włączono 24081 pacjentów z 926 ośrodków na całym świecie, których poddano randomizacji do trzech grup otrzymujących, kolejno, celekoksyb w dawce 100 mg 2 razy/dobe, ibuprofen w dawce 3 razy/dobę lub naproksen w dawce $375 \mathrm{mg} 2$ razy/dobę. Wszyscy pacjenci otrzymywali osłonowo inhibitor pompy protonowej (esomeprazol w dawce 20-40 mg/d.). Średni okres ekspozycji na NLPZ wynosił ponad 20 miesięcy, a średni okres obserwacji - 34 miesiące. Dawka każdego z NLPZ mogła być zwiększana w przypadku nieustąpienia objawów i wynosiła ona średnio: 104 mg 2 razy/dobę w przypadku celekoksybu, $681 \mathrm{mg} 3$ razy/dobę w przypadku ibuprofenu, $426 \mathrm{mg} 2$ razy/dobę w przypadku naproksenu. W czasie badania $68,8 \%$ pacjentów zaprzestało leczenia za pomocą NLPZ. Pierwszorzędowy złożony punkt końcowy, służący ocenie non-inferiority stosowania celeksksybu względem pozostałych dwóch szeroko stosowanych NLPZ, uwzględniał wystąpienie zgonu z przyczyn sercowo-naczyniowych (w tym zgonu z powodu krwawienia), niezakończonego zgonem zawału serca oraz niezakończonego zgonem udaru mózgu. Złożony punkt końcowy wystąpił u 188 (2,3\%) chorych otrzymujących celekoksyb, 201 (2,5\%) przyjmujących naproksen oraz 218 (2,7\%) przyjmujących ibuprofen, wskazując, że terapia celekoksybem nie była gorsza od leczenia pozostałymi dwoma rodzajami NLPZ ( $p$ dla non-inferiority < 0,001 dla obu porównań). Ryzyko wystąpienia niekorzystnych zdarzeń ze strony układu pokarmowego (w tym incydentów krwawienia związanych z nową niedokrwistością zdefiniowaną jako spadek odsetka hematokrytu $>10 \%$ lub stężenia hemoglobiny $>2 \mathrm{~g} / \mathrm{dl}$ ) było istotnie niższe w grupie otrzymującej celekoksyb względem pacjentów otrzymujących naproksen $(p=0,01)$ oraz ibuprofen $(p=0,002)$. Również istotne powikłania nerkowe (w tym hospitalizacja z powodu niewydolności nerek) występowały rzadziej u chorych otrzymujących celekoksyb niż u otrzymujących ibuprofen $(p=0,004)$, jednak nie względem otrzymujących naproksen $(p=0,19)$. Autorzy we wnioskach podkreślają, że celekoksyb w umiarkowanej dawce okazał się lekiem przynajmniej tak samo bezpiecznym jak ibuprofen czy naproksen pod względem bezpieczeństwa sercowo-naczyniowego [2]. Samo badanie wydaje się istotnym ostrzeżeniem przed zbyt pochopnym ekstrapolowaniem wniosków z małych, nierandomizowanych badań klinicznych, które były przyczyną wieloletniej marginalizacji tej grupy NLPZ.

\section{Choroba niedokrwienna serca}

Nieoczekiwane wyniki przyniosło jedno z nielicznych dużych prospektywnych badań z dziedziny kardiochirurgii o akronimie ART (Arterial Revascularization Trial) zapoczątkowane w 2004 roku. Podjęto w nim niezwykle nurtującą kwestię korzyści płynących z obustronnego wykorzystania tętnic piersiowych wewnętrznych (IMA, internal mammary artery) podczas pomostowania aortalno-wieńcowego (CABG, coronary artery bypass grafting). Nie brakuje dowodów przemawiających za istotną wyższością pomostów tętniczych (lewa tętnica piersiowa wewnętrzna) nad żylnymi w długoterminowych obserwacjach, co stało się bodźcem do wdrożenia techniki operacyjnej z wykorzystaniem obustronnych pomostów z IMA. Niemniej jednak odsetek zabiegów CABG wykorzystujących jednocześnie lewą (LIMA, left internal mammary artery) i prawą (RIMA, right internal mammary artery) IMA wciąż jest niski (< 10\% w Europie oraz < 5\% w Stanach Zjednoczonych), głównie ze względu na techniczną trudność tego typu zabiegu, przy braku randomizowanych badań klinicznych faworyzujących tego typu podejście. Badanie ART miało umożliwić jednoznaczną odpowiedź na pytanie, czy obustronne wykorzystanie IMA poprawia rokowanie u pacjentów kierowanych na CABG. Pierwszorzędowym punktem końcowym był zgon z jakiekolwiek przyczyny, natomiast drugorzędowym złożonym punktem końcowym - zgon z jakiejkolwiek przyczyny, zawał serca lub udar mózgu. W badaniu wzięło udział 28 ośrodków kardiochirurgicznych z siedmiu krajów, w tym Polski. Do badania włączono 3102 pacjentów z wielonaczyniową chorobą niedokrwienną serca, bez wcześniej przebytego CABG oraz współistniejących istotnych wad zastawkowych wymagających operacji. Pacjentów poddano randomizacji do 2 grup chorych, u których wykonano: 1) pojedynczy pomost tętniczy (LIMA do gałęzi przedniej zstępującej + pomost/y żylny/e lub tętnicze z wykorzystaniem tętnicy promieniowej do pozostałych naczyń; $n=1554), 2$ ) obustronny pomost tętniczy (LIMA i RIMA do dwóch istotnych gałęzi lewej tętnicy wieńcowej + pomost/y żylny/e lub tętnicze z wykorzystaniem tętnicy promieniowej do pozostałych naczyń; $n=1548$ ). Badanie zaplanowano na okres 10-letniej obserwacji, jednak komitet naukowy zdecydował się opublikować wstępne wyniki obserwacji 5-letniej, będące przedmiotem niniejszego doniesienia. Średni wiek pacjentów wynosił 63 lata; większość stanowili mężczyźni (85\%), a niespełna co 4. pacjent chorował na cukrzyce (23\%). Blisko połowę zabiegów $(40,6 \%)$ przeprowadzono bez wykorzystania krążenia pozaustrojowego (OPCAB, off-pump coronary artery bypass), wykonując średnio trzy pomosty naczyniowe w obu grupach. U 16,4\% pacjentów z grupy obustronnej IMA nie udało się ostatecznie wykorzystać obu tętnic jako pomostów naczyniowych. Obie techniki nie różniły się istotnie w zakresie 5-letniej śmiertelności całkowitej (8,7\% w grupie obustronnej IMA v. 8,4\% w grupie LIMA; 
$p=0,77$ ), nawet po skorygowaniu o takie zmienne, jak wiek, płeć, współistniejąca cukrzyca oraz frakcja wyrzutowa lewej komory (LVEF, left ventricular ejection fraction) (HR $=1,03$, 95-proc. przedział ufności $[\mathrm{Cl}$, confidence interval] 0,81-1,32; $p=0,8)$. Ponadto nie obserwowano również istotnych różnic $w$ zakresie złożonego punktu końcowego (zgon, zawał serca lub udar), który obserwowano u 12,2\% pacjentów z obustronnym w porównaniu z 12,7\% pacjentami z jednostronnym pomostem tętniczym $(p=0,69)$. Również analiza w podgrupach nie wykazała istotnych interakcji wskazujących na lepsze przeżycia pacjentów z obustronnym pomostem tętniczym zależnie od wieku, techniki operacyjnej (off pump v. on pump), liczby pomostów, LVEF oraz współistniejącej cukrzycy. Poza tym podobny odsetek pacjentów w obu grupach (70\%) w okresie obserwacji 5-letniej nie zgłaszał żadnych dolegliwości dławicowych, a także nie obserwowano istotnych różnic pod względem częstości istotnych krwawień oraz konieczności reoperacji. Natomiast potwierdzono w tym badaniu wcześniejsze obawy dotyczące problemów z gojeniem się rany pooperacyjnej - ryzyko infekcji rany było blisko 2-krotnie wyższe $(3,5 \%$ v. 1,9\%; HR =1,89; 95\% Cl 1,2-2,92; $p=0,005$ ), a konieczność chirurgicznej rekonstrukcji rany blisko 3-krotnie wyższa (1,9\% v. 0,6\%; HR = 2,91; 95\% Cl 1,42-5,95; $p=0,002)$ u pacjentów z obustronnym wykorzystaniem IMA. Powikłania te obserwowano w szczególności u chorych ze współistniejącą cukrzycą i wyższym wskaźnikiem masy ciała (BMI, body mass index). Dość zaskakujące zatem wyniki badania ART sugerują, że strategia rewaskularyzacji tętniczej z obustronnym wykorzystaniem IMA nie poprawia rokowania pacjentów kierowanych na CABG, jednocześnie w istotny sposób zwiększając ryzyko powikłań ze strony rany pooperacyjnej. Należy jednak pamiętać, że badanie zaplanowano na 10-letnią obserwację, więc na ostateczne wynik pozostaje jeszcze zaczekać do 2018 roku [3].

Szczególnie wyczekiwanym, jak również wnoszącym wiele implikacji klinicznych było zaprezentowane podczas ubiegłorocznego kongresu badanie PIONEER AF-PCI (A Study Exploring Two Strategies of Rivaroxaban and One of Oral Vitamin K Antagonist in Patients With Atrial Fibrillation Who Undergo Percutaneous Coronary Intervention) realizowane w dużym zakresie także przez ośrodki polskie. Jest ono pierwszym randomizowanym badaniem służącym odpowiedzi na pytanie, czy zastosowanie nowych doustnych antykoagulantów niebędących antagonistami witaminy $\mathrm{K}$ (NOAC, non-vitamin K oral anticoagulants) może poprawić profil bezpieczeństwa w porównaniu z leczeniem przeciwkrzepliwym doustnymi antagonistami witaminy K (VKA, vitamin $K$ antagonists) u pacjentów z niezastawkowym migotaniem przedsionków (AF, atrial fibrillation) poddawanych przezskórnej interwencji wieńcowej (PCI, percutaneous coronary intervention) z implantacją stentu (AF współistnieje u blisko 5-8\% pacjentów poddawanych PCl), wymagająca dodatkowego leczenia przeciwkrzepliwego.
W aktualnych wytycznych u tych pacjentów zaleca się zastosowanie terapii potrójnej będącej kombinacją leczenia przeciwkrzepliwego (NOAC/VKA) z podwójną terapią przeciwpłytkową (DAPT, dual anti-platelet therapy) na okres zależny od indywidualnego ryzyka krwawień ocenianego w skali HAS-BLED. Należy natomiast zaznaczyć, że obecnie z powodu braku wiarygodnych badań łączenie NOAC z nowymi inhibitorami P2Y 12 (tikagrelor oraz prasugrel) było przeciwwskazane mimo udowodnionych korzyści z ich stosowania w grupie pacjentów po PCl bez współistniejącego AF. Jak dotychczas w żadnym randomizowanym badaniu nie oceniano bezpośrednio bezpieczeństwa i skuteczności leczenia przeciwkrzepliwego NOAC względem VKA w kombinacji z DAPT u pacjentów z niezastawkowym AF poddawanych $\mathrm{PCl}$, a rekomendacje i aktualne wytyczne były oparte na wynikach subanaliz badań, w których jedynie pewien odsetek stanowili chorzy z AF.

Badanie PIONIEER AF było wieloośrodkowym badaniem, do którego włączono 2124 pacjentów z niezastawkowym AF, u których wykonano PCl z implantacją stentu. Pacjentów poddano randomizacji do trzech różnych strategii leczenia (randomizacja 1:1:1):

- riwaroksaban raz/dobę (15 mg/d. lub $10 \mathrm{mg} / \mathrm{d}$. w przypadku umiarkowanej niewydolności nerek - filtracja kłębuszkowa [GFR, glomerular filtration rate] $<50 \mathrm{ml} / \mathrm{min}$ ) + inhibitor receptora płytkowego $\mathrm{P} 2 \mathrm{Y}_{12}$ (klopidogrel $75 \mathrm{mg} / \mathrm{d}$. lub tikagrelor $2 \times 90 \mathrm{mg} / \mathrm{d}$. lub prasugrel $10 \mathrm{mg} / \mathrm{d}$.) przez 12 miesięcy (grupa 1.);

- mała dawka riwaroksabanu $(2 \times 2,5 \mathrm{mg} / \mathrm{d}$.) + DAPT (kwas acetylosalicylowy [ASA, acetylicylid acid] 75-100 mg/d. + klopidogrel $75 \mathrm{mg} / \mathrm{d}$. lub tikagrelor $2 \times 90 \mathrm{mg} / \mathrm{d}$. lub prasugrel $10 \mathrm{mg} / \mathrm{d}$.) przez 1, 6 lub 12 miesięcy (grupa 2.); chorzy poddani 1- lub 6-miesięcznej terapii potrójnej otrzymywali następnie do 12 miesięcy od PCl riwaroksaban w dawce $15 \mathrm{mg} /$ dobę (10 mg w przypadku umiarkowanego stopnia upośledzenia funkcji nerek) + ASA 75-100 mg/dobę;

- standardowa terapia VKA (warfaryną) według wartości międzynarodowego wskaźnika znormalizowanego (INR, international normalized ratio) (docelowo 2,0-3,0) + DAPT przez 1, 6 lub 12 miesięcy (75-100 mg ASA/d. + klopidogrel $75 \mathrm{mg} / \mathrm{d}$. lub tikagrelor $2 \times 90 \mathrm{mg} / \mathrm{d}$. lub prasugrel $10 \mathrm{mg} / \mathrm{d}$.) (grupa 3.); chorzy poddani 1- lub 6-miesięcznej terapii potrójnej otrzymywali następnie do 12 miesięcy od PCl lek z grupy VKA według wartości INR (docelowo 2,0-3,0) + ASA 75-100 mg/dobę.

Okres terapii potrójnej w grupach 2. i 3. (terapia 1-, 6- lub 12-miesięczna) zależał od decyzji lekarza prowadzącego i został ustalony przed poddaniem chorego randomizacji (odsetek chorych poddanych terapii potrójnej kolejno przez 1, 6 i 12 miesięcy w grupie 2. 16\%, 35\% i $49 \%$ v. 16\%, 35\%, 49\% w grupie 3.). Z badania wykluczono pacjentów z przebytym wcześniej epizodem udaru ośrodkowego układu nerwowego (OUN)/przejściowego 
napadu niedokrwiennego, epizodem krwawienia z układu pokarmowego oraz z niewydolnością nerek (GFR $<30 \mathrm{ml}$ / /min). Ocenianym pierwszorzędowym klinicznym punktem końcowym w zakresie bezpieczeństwa było wystąpienie istotnego krwawienia (krwawienia małe lub duże w skali TIMI [Thrombolysis In Myocardial Infarction] lub wymagające kontaktu z opieką zdrowotną). Ponadto autorzy zaprezentowali wyniki analizy post-hoc w zakresie śmiertelności całkowitej oraz konieczności rehospitalizacji. Mediana wieku badanych wynosiła 71 lat, mediana punktacji w skali $\mathrm{CHA}_{2} \mathrm{DS}_{2}$-VASc -4 punkty, a w skali HAS-BLED - 2 punkty. $\mathrm{U}$ ponad połowy chorych $\mathrm{PCl}$ wykonano w przebiegu ostrego zespołu wieńcowego (51,6\%), a co 3. (66,1\%) pacjentowi implantowano stent uwalniający lek (DES, drug-eluting stent). Częstość krwawień w obu grupach leczonych riwaroksabanem była istotnie mniejsza niż wśród pacjentów poddanych standardowej terapii VKA (16,8\% w grupie 1.; 18,0\% w grupie 2. i 26,7\% w grupie 3.; HR w grupie 1. v. grupa 3. $=0,59$ z 95\% Cl 0,47-0,76; $p<0,001 ;$ HR w grupie 2 . v. grupa 3. =0,63 z 95\% Cl 0,50-0,80; $p<0,001$ ). Ponadto nie obserwowano istotnych różnic w zakresie częstości złożonego punktu końcowego pod postacią zgonu z przyczyn sercowo-naczyniowych, zawału serca lub udaru mózgu między badanymi grupami (kolejno w grupach 1. - 6,5\%, 2. $-5,6 \%$ oraz 3. $-6 \%$ ). Co bardzo interesujące, częstość zakrzepicy w implantowanym stencie było relatywnie niska we wszystkich grupach, bez istotnych statystycznie różnic między nimi (grupy: 1. - 0,8\%, 2. - 0,9\%, 3. - 0,7\%), a, co szczególnie zwraca uwagę, zastosowanie terapii podwójnej (riwaroksaban + inhibitor receptora płytkowego $\mathrm{P}_{2} \mathrm{Y}_{12}$ ), bez ASA, nie wiązało się z większą częstością wczesnej zakrzepicy w stencie. Częstość udarów OUN była zbliżona w przypadkach wszystkich trzech strategii farmakoterapii (grupy: 1. - 1,3\%, $2-1,5 \%$, 3. - 1,2\%; p1 v. $3=0,89$; p2 v. $3=0,53)$. Natomiast częstość zgonu z jakiejkolwiek przyczyny lub rehospitalizacji była istotnie niższa zarówno wśród pacjentów z grupy 1. w porównaniu z 3. (34,9\% v. 41,9\%; $\mathrm{HR}=0,79 ; 95 \% \mathrm{Cl} 0,66-0,94 ; \mathrm{p}=0,008$; NNT [number needed to treat] $=15$ ), jak i wśród pacjentów z grupy 2. w porównaniu z 3. ( $\mathrm{HR}=0,75 ; 95 \% \mathrm{Cl} 0,62-0,90$; $p=0,002 ;$ NNT $=10$ ). Istotnie wyższy odsetek zgonów i rehospitalizacji w grupie otrzymującej VKA + DAPT wynikał głównie z częstszych krwawień (grupa 1. - 8,6\% [p $=0,032$ v. grupa 3.], grupa 2. $-8,0 \%[p=0,012$ v. grupa 3], grupa 3. - 12,4\%), a także z przyczyn sercowo-naczyniowych (grupa 1. - 21,4\% [p=0,001 v. grupa 3.], grupa 2. $-21,70 \%$ [p=0,011 v. grupa 3.], grupa 3. 29,3\%). Wydaje się, że wyniki badania PIONIEER AF istotnie zmienią dotychczasowe wytyczne w zakresie farmakoterapii pacjentów ze współistniejącym AF po koronaroplastyce zakończonej implantacją stentu. Zapewne przechylają one szalę korzyści i poprawy bezpieczeństwa w stronę NOAC (riwaroksaban), jak również wydaje się, że pozwolą uznać za bezpieczną w wybranej grupie pacjentów terapię podwójną (riwaroksaban + inhibitor receptora przeciwpłytkowego $\mathrm{P} \mathrm{Y}_{12}$ przez 12 miesięcy). Ponadto badanie to stanie się zapewne podstawą akceptacji kojarzenia NOAC (riwaroksaban) z nowymi inhibitorami receptora płytkowego P2Y ${ }_{12}$ (tikagrelor, prasugrel), których do tej pory nie zalecano[4, 5].

\section{Niewydolność serca}

Ubiegłoroczny kongres AHA obfitował w wyniki badań służących weryfikacji korzyści z suplementacji żelaza w grupie pacjentów z niewydolnością serca, gdzie u blisko co drugiego chorego obserwuje się niedobory tego mikroelementu. Wiele wątpliwości wciąż dotyczy najoptymalniejszej drogi suplementacji żelaza (doustna v. dożylna) oraz związanych z tym korzyści, a zaprezentowane badania IRONOUT HF (Oral Iron Repletion effecton Oxygen UpTake in Heart Failure) oraz EFFECT HF (Effect of Ferric Carboxymaltose on Exercise Capacity in Patients with Iron Deficiency and Chronic Heart Failure) rzucają nowe światło na ten problem.

W badaniu IRONOUT HF autorzy oceniali, czy doustna suplementacja kompleksu polisacharydowego żelaza $(300 \mathrm{mg} / \mathrm{d}$.) względem placebo wpływa na poprawę tolerancji wysiłku fizycznego w grupie 225 pacjentów z niewydolnością serca (II-IV klasa wg New York Heart Association [NYHA]) z obniżoną frakcją wyrzutową (HFrEF [heart failure with reduced ejection fraction] zdefiniowana jako $\mathrm{EF}<40 \%$ ) oraz obniżonymi zasobami ustrojowymi żelaza (stężenie ferrytyny < 100 ng/ml lub 100-299 ng/ml i jednoczesny poziom wysycenia transferryny $<20 \%$; stężenie hemoglobiny $<13,5 \mathrm{~g} / \mathrm{dl}$ u kobiet $\mathrm{i}<15 \mathrm{~g} / \mathrm{dl}$ u mężczyzn). Ocenianym pierwszorzędowym punktem końcowym była zmiana wartości szczytowego wysiłkowego pochłaniania tlenu $\left(\mathrm{VO}_{2}\right.$ peak) w obserwacji 16-tygodniowej. Drugorzędowymi punktami końcowymi były ocena wpływu suplementacji preparatu żelaza na poziom tolerowanego wysiłku fizycznego, osoczowe wartości N-końcowego propeptydu natriuretycznego (NT-proBNP, N-terminal B-type natriuretic propetide) oraz jakość życia. Uzyskane wyniki nie wykazały istotnych różnic w zakresie zmiany $\mathrm{VO}_{2}$ peak, poprawy tolerancji wysiłku fizycznego (ocenianego w teście 6-minutowego marszu) ani obniżenia wartości NT-proBNP między grupą otrzymująca placebo a pacjentami przyjmującymi doustną suplementację żelaza. Dodatkowo badacze obserwowali jedynie nieznaczną poprawę ustrojowych zapasów żelaza (stężenie ferrytyny wzrosło o $11 \mathrm{ng} / \mathrm{ml}$, a poziom wysycenia transferryny o $3 \%$, pozostając cały czas poniżej normy) przy zastosowanej relatywnie dużej dawce doustnej suplementacji. Autorzy, konkludując, stwierdzili, że doustna suplementacja żelaza w grupie pacjentów z HFrEF nie jest uzasadniona w świetle otrzymanych wyników, głównie ze względu na minimalną przyswajalność w przypadku tej drogi podania [6].

W badaniu EFFECT-HF natomiast podjęto próbę oceny wpływu parenteralnej (dożylnej) suplementacji kompleksu 
karboksymaltozy żelazowej na poprawę tolerancji wysiłku fizycznego względem standardowej terapii niewydolności serca pozbawionej suplementacji żelaza. Do badania włączono łącznie 174 pacjentów ze stabilną przewlekłą niewydolnością serca (II-III klasa wg NYHA; stężenie NT-proBNP > $400 \mathrm{pg} / \mathrm{ml}$ ) z obniżoną LVEF (EF $\leq 45 \%)$ oraz niedoborem żelaza (stężenie ferrytyny $<100 \mathrm{ng} / \mathrm{ml}$ lub $100-300 \mathrm{ng} / \mathrm{ml}$ oraz poziom wysycenia transferryny $<20 \%$ i stężenie hemoglobiny < $15 \mathrm{~g} / \mathrm{dl}$ ). Pacjenci w grupie poddanej interwencji, poza standardową farmakoterapią niewydolności serca, otrzymywali trzy dawki karboksymaltozy żelazowej dożylnie w momencie randomizacji oraz po 6 i 12 tygodniach (średnia dawka 1204 mg). Pierwszorzędowym punktem końcowym była zmiana $\mathrm{VO}_{2}$ peak po 24 tygodniach obserwacji, które istotnie wzrosło w grupie pacjentów otrzymujących dożylną suplementację żelaza (średnia różnica między grupami $\Delta \mathrm{pVO}_{2}=1,32 \pm 0,51 \mathrm{ml} / \mathrm{kg}$ $\mathrm{mc} . / \mathrm{min} ; \mathrm{p}=0,02)$. Ponadto dożylna suplementacja żelaza wiązała się z istotną poprawą klasy czynnościowej według NYHA oraz subiektywnej oceny stanu zdrowia pacjenta [7].

Przedstawione wyniki badań, będące poparciem wcześniejszych doniesień (FAIR-HF1, CONFIRM-HF2), pozwalają wnioskować, że suplementacja preparatów żelaza u pacjentów z przewlekła niewydolnością serca oraz towarzyszącym jego niedoborem ma uzasadnienie jedynie drogą dożylną, mimo że jest to dużo droższa forma terapii.

\section{Dyslipidemie}

Badania, których podstawą jest modyfikacja procesów patofizjologicznych na poziomie interferencji z materiałem genetycznym, stają się faktem, otwierając ogromne możliwości terapeutyczne. Z dużym zainteresowaniem przyjęto zatem wyniki II fazy klinicznej badania ORION 1. Badanie to oparto na koncepcji inhibitorów konwertazy białkowej subtylizyny/keksyny typu 9 (PCSK9, proprotein convertase subtilisin/kexin type 9) - białka odgrywającego kluczową rolę w metabolizmie lipidów, którego inhibicja prowadzi do istotnego obniżenia osoczowych stężeń cholesterolu frakcji LDL (low-density lipoprotein). W prezentowanym badaniu (w przeciwieństwie do poprzednich badań, w których wykorzystano przeciwciała monoklonalne anty-PCSK9 - ewelokumab i alirokumab) inhibicji syntezy PCSK9 dokonano na poziomie interferencji z materiałem genetycznym - informacyjnym RNA (mRNA) odpowiedzialnym za syntezę PCSK9. W omawianym badaniu wykorzystano innowacyjną cząsteczkę - inclisiran (ALN-PCSsc), tj. długodziałającego, syntetycznego, 21-23-nukleotydowego antagonistę mRNA odpowiedzialnego za bezpośrednią syntezę PCSK9, zmodyfikowanego poprzez przyłączenie cząsteczek N-acetylogalaktozaminy, co predysponuje do szczególnie wysokiego wychwytu tych cząsteczek w hepatocytach. Inclisiran łączy się z mRNA PCSK9, inicjując jego degradację, a tym samym blokuje translację i syntezę finalnego białka. Do badania włączono pacjentów otrzymujących maksymalną tolerowaną dawkę statyny, którzy nie osiągnęli docelowej wartości cholesterolu frakcji LDL. Osoby te poddano randomizacji do grupy otrzymującej placebo ( $n=127)$ lub inclisiran podskórnie $(n=374)$ w czterech różnych dawkach (100mg, 200 mg, 300 mg lub 500 mg). Wyjściowe stężenie cholesterolu frakcji LDL wynosiło około $130 \mathrm{mg} / \mathrm{dl}$. Po 90 dniach od pierwszego wstrzyknięcia obserwowano istotne obniżenie wartości cholesterolu frakcji LDL (efekt nie zależał w sposób istotny od dawki), który dla dawki 300 mg wynosił 51\% wartości wyjściowej. Natomiast przy powtórzeniu dawki 300 mg w 90. dobie obserwowano dalsze obniżenia wartości cholesterolu frakcji LDL, którego redukcja w 180. dobie od pierwszego wstrzyknięcia wynosiła 57\% wartości wyjściowej. W grupie otrzymującej dawkę 300 mg inclisiranu średnie obniżenie stężenia cholesterolu frakcji LDL wynosiło $64 \mathrm{mg} / \mathrm{dl}$ w 180. dobie (zakres redukcji wartości cholesterolu frakcji LDL 26-122 mg/dl) i, co szczególnie podkreślili autorzy, obniżenie to obserwowano u wszystkich pacjentów z badanej grupy. Maksymalny efekt redukcji wartości cholesterolu frakcji LDL obserwowano około 60. doby od podania leku i pozostawał on stały do 90 . doby po iniekcji, potencjalnie pozwalając stosować 3 dawki tego leku rocznie, co wydaje się niezwykle atrakcyjną perspektywą terapeutyczną. Ponadto $w$ badaniu tym potwierdzono bezpieczeństwo stosowania tego typu innowacyjnej terapii, ponieważ nie obserwowano istotnych działań niepożądanych względem grupy otrzymującej placebo, w tym wzrostu stężenia enzymów wątrobowych, miopatii oraz zaburzenia funkcji nerek. Najczęściej stwierdzanymi objawami niepożądanymi związanymi z terapią (> 2\%) były: bóle mięśniowe, bóle głowy, zmęczenie, zapalenie nosogardła, bóle pleców, biegunki i zawroty głowy. U 12 (3,2\%) chorych obserwowano niepożądane odczyny skórne w miejscu podania leków niewymagające przerwania leczenia. Badanie to dało „zieIone światło" III fazie klinicznej testowania tej niezwykle obiecującej terapii, która - jak wszystko wskazuje - może się stać kolejnym, po przeciwciałach monoklonalnych anty-PCSK, przełomowym krokiem w terapii dyslipidemii [8].

\section{Piśmiennictwo}

1. Hiatt WR, Fowkes FG, Heizer G, et al. EUCLID Trial Steering Committee and Investigators. Ticagrelor versus clopidogrel in symptomatic peripheral artery disease. N Engl J Med. 2017; 376(1): 32-40, doi: 10.1056/NEJMoa1611688, indexed in Pubmed: 27959717.

2. Nissen SE, Yeomans ND, Solomon DH, et al. PRECISION Trial Investigators. Cardiovascular safety of celecoxib, naproxen, or ibuprofen for arthritis. N Engl J Med. 2016; 375(26): 2519-2529, doi: 10.1056/ /NEJMoa1611593, indexed in Pubmed: 27959716.

3. Taggart DP, Altman DG, Gray AM, et al. ART Investigators. Randomized trial of bilateral versus single internal-thoracic-artery grafts. N Engl J Med. 2016; 375(26): 2540-2549, doi: 10.1056/NEJMoa1610021, indexed in Pubmed: 27959712. 
4. Gibson CM, Pinto DS, Chi G, et al. Recurrent hospitalization among patients with atrial fibrillation undergoing intracoronary stenting treated with 2 treatment strategies of rivaroxaban or a dose-adjusted oral vitamin K antagonist treatment strategy. Circulation. 2017; 135(4): 323-333, doi: 10.1161/CIRCULATIONAHA.116.025783, indexed in Pubmed: 27881555.

5. Gibson CM, Mehran R, Bode C, et al. Prevention of bleeding in patients with atrial fibrillation undergoing PCl. N Engl J Med. 2016; 375(25): 2423-2434, doi: 10.1056/NEJMoa1611594, indexed in Pubmed: 27959713.

6. Lewis GD, McNulty S, Hernandez AF, et al. Oral iron repletion effects on oxygen uptake in heart failure (IRONOUT HF). American
Heart Association 2016 Scientific Sessions. November 16, 2016. New Orleans.

7. Van Veldhuisen DJ, Ponikowski P, Metra M, et al. Effect of ferric carboxymaltose on exercise capacity in patients with iron deficiency and chronic heart failure (EFFECT-HF): a randomized controlled study. American Heart Association 2016 Scientific Sessions. November 16, 2016. New Orleans.

8. Ray KK, Landmesser U, Leiter LA, et al. Insights from new therapeutic trials for lipids. ORION-1. Inclisiran inhibits PCSK9 synthesis by RNA interference. Planned interim analysis of a multi-center randomized controlled dose-finding trial. American Heart Association's Scientific Sessions 2016. November 12-16, 2016. New Orleans. 